\title{
Kocuria marina sp. nov., a novel actinobacterium isolated from marine sediment
}

\author{
Seung Bum Kim, ${ }^{1}$ Olga I. Nedashkovskaya, ${ }^{2}$ Valery V. Mikhailov, ${ }^{2}$ \\ Suk Kyun Han, ${ }^{1}$ Kyoung-Ok Kim, ${ }^{1}$ Moon-Soo Rhee ${ }^{1}$ and Kyung Sook Bae ${ }^{1}$ \\ ${ }^{1}$ Korean Collection for Type Cultures, Korea Research Institute of Bioscience and \\ Biotechnology, 52 Oun Dong, Yusong, Daejon 305-333, Republic of Korea \\ ${ }^{2}$ Pacific Institute of Bioorganic Chemistry of Far-Eastern Branch of the Russian Academy of \\ Sciences, Pr. 100 Let Vladivostoku, 159, Vladivostok, 690022, Russia
}

\begin{abstract}
An actinobacterial strain was isolated from marine sediment taken from the Troitsa Bay of the Gulf of Peter the Great, East Siberian Sea, and subjected to a taxonomic investigation. The isolate, designated $\mathrm{KMM} 3905^{\top}$, was Gram-positive, aerobic, non-motile and coccoid. The strain tolerated up to $15 \% \mathrm{NaCl}$ in growth media, although its presence was not essential for growth. Chemotaxonomic and phylogenetic properties of the strain were consistent with its classification in the genus Kocuria. The strain formed an independent phylogenetic line in the 16S rRNA gene tree encompassed by members of Kocuria. Comparison of phenotypic characteristics also supported its assignment to a novel species within Kocuria. The name Kocuria marina sp. nov. (type strain $\mathrm{KMM} 3905^{\top}=\mathrm{KCTC} 9943^{\top}$ ) is proposed for this halotolerant actinobacterium from the marine environment.
\end{abstract}

The genus Kocuria was first proposed by Stackebrandt et al. (1995) to accommodate phylogenetically distinct actinobacteria formerly classified in the genus Micrococcus, within which heterogeneity had been suggested in earlier studies (Kloos, 1969; Ogasawara-Fujita \& Sakaguchi, 1976). Kocuria is clearly separated from Micrococcus and other related Gram-positive cocci such as Arthrobacter and Rothia in phylogenetic analyses using 16S rRNA gene sequences (Stackebrandt et al., 1995).

Six species with validly published names currently comprise the genus, namely Kocuria kristinae, Kocuria palustris, Kocuria polaris, Kocuria rhizophila, Kocuria rosea and Kocuria varians (Stackebrandt et al., 1995; Kovács et al., 1999; Reddy et al., 2003). Members of Kocuria are Gram-positive, aerobic, coccoid, non-encapsulated, nonhalophilic and non-endospore-forming. Their normal habitats include mammalian skin, soil, the rhizoplane and fresh water (Kloos et al., 1974; Kocur, 1986; Kovács et al., 1999). Little is known regarding their pathogenicity to humans and other mammals, but they are not considered to be a primary pathogen (Kocur, 1986; Kocur et al., 1991).

Members of Kocuria are characterized by the presence of menaquinones $\mathrm{MK}-7\left(\mathrm{H}_{2}\right)$ and $\mathrm{MK}-8\left(\mathrm{H}_{2}\right)$, lysine-based A $3 \alpha$-type peptidoglycan, PI-type phospholipids and

Published online ahead of print on 27 February 2004 as DOI 10.1099/ ijs.0.02742-0.

The GenBank/EMBL/DDBJ accession number for the 16S rRNA gene sequence of strain $\mathrm{KMM} 3905^{\top}$ is AY2 11385. saturated branched fatty acids (anteiso- $\mathrm{C}_{15: 0}$ as the major component) in their cell envelopes (Stackebrandt et al., 1995). The $\mathrm{G}+\mathrm{C}$ content of the genomic DNA ranges from 66 to 75 mol\% (Boháček et al., 1969; Kloos et al., 1974; Kocur et al., 1971; Kovács et al., 1999; Reddy et al., 2003).

There is no record on the isolation of strains belonging to the genus Kocuria from the marine environment, although many members exhibit tolerance to high salt concentrations (Stackebrandt et al., 1995; Kovács et al., 1999). During an investigation exploring bacterial diversity in the marine environment in the Gulf of Peter the Great, East Siberian Sea, a coccoid actinobacterial strain was isolated and designated KMM $3905^{\mathrm{T}}$. The strain was subjected to a polyphasic investigation, and its taxonomic position is discussed below.

Strain KMM $3905^{\mathrm{T}}$ was isolated from a marine sediment sample taken from Troitsa Bay. After primary isolation and purification on marine agar 2216 (Difco) at $28^{\circ} \mathrm{C}$, the strain was subcultured on the same medium and stored at $-80{ }^{\circ} \mathrm{C}$ in marine broth (Difco) supplemented with $20 \%$ (v/v) glycerol.

The presence of enzyme activities, degradation of organic compounds, growth on $\mathrm{NaCl}$, production of acid from carbohydrates, susceptibility to antibiotics and other physiological characteristics of the organism were determined as described by Han et al. (2003). DNA extraction, PCR and sequencing of $16 S$ rRNA genes were performed according to previously described procedures (Kim et al., 
1998). The 16S rRNA gene sequence obtained was aligned together with those of representative members of Kocuria using PHYDIT version 3.2 (http://plaza.snu.ac.kr/ jchun/ phydit/). Phylogenetic trees were inferred using suitable programs of the PHYLIP package (Felsenstein, 1993). Phylogenetic distances were calculated from the model of Kimura

Table 1. Phenotypic properties that separate $\mathrm{KMM} 3905^{\top}$ and six other species of the genus Kocuria

Strain/species: 1, KMM 3905 ${ }^{\mathrm{T}}$; 2, K. kristinae; 3, K. palustris; 4, K. polaris; 5, K. rhizophila; 6, K. rosea; 7, K. varians. Data for reference species were taken from Stackebrandt et al. (1995), Kovács et al. (1999) and Reddy et al. (2003). +, Positive; (+), weakly positive; - , negative; $\mathrm{V}$, results variable between strains; ND, not determined.

\begin{tabular}{|c|c|c|c|c|c|c|c|}
\hline Property & 1 & 2 & 3 & 4 & 5 & 6 & 7 \\
\hline Oxidase & - & - & - & + & - & - & - \\
\hline Alkaline phosphatase & - & - & - & - & + & - & - \\
\hline Urease & + & - & + & - & - & - & + \\
\hline Nitrate reduction & + & - & + & + & - & + & - \\
\hline $\mathrm{H}_{2} \mathrm{~S}$ production & - & - & $(+)$ & ND & $(+)$ & - & - \\
\hline \multicolumn{8}{|l|}{ Hydrolysis of: } \\
\hline Gelatin & + & $(+)$ & + & - & - & + & - \\
\hline Starch & - & - & - & - & - & + & - \\
\hline Tween 80 & - & + & + & $\mathrm{ND}$ & + & - & + \\
\hline Urea & + & - & + & - & - & - & + \\
\hline \multicolumn{8}{|l|}{ Growth at/in: } \\
\hline $5^{\circ} \mathrm{C}$ & + & - & - & + & - & - & - \\
\hline $37^{\circ} \mathrm{C}$ & + & + & - & - & + & + & + \\
\hline $5 \% \mathrm{NaCl}$ & + & + & $(+)$ & - & + & + & + \\
\hline $10 \% \mathrm{NaCl}$ & + & + & - & - & + & - & - \\
\hline $15 \% \mathrm{NaCl}$ & + & - & - & - & $(+)$ & - & - \\
\hline \multicolumn{8}{|c|}{ Utilization as sole carbon source: } \\
\hline Adonitol & - & + & + & + & + & - & + \\
\hline L-Arabinose & - & + & - & + & + & + & + \\
\hline meso-Inositol & - & + & - & + & - & - & - \\
\hline Mannitol & - & + & - & - & - & + & - \\
\hline Mannose & + & + & - & ND & + & + & + \\
\hline Melibiose & - & & & & & & \\
\hline Sorbitol & - & + & - & ND & - & + & + \\
\hline \multicolumn{8}{|c|}{ Acid production from: } \\
\hline L-Arabinose & - & - & - & ND & - & + & - \\
\hline Galactose & - & - & + & $\mathrm{ND}$ & - & - & - \\
\hline Glucose & - & + & + & + & + & + & $\mathrm{V}$ \\
\hline Glycerol & - & + & - & $\mathrm{ND}$ & - & - & - \\
\hline Lactose & - & - & - & $\mathrm{ND}$ & + & - & + \\
\hline Maltose & - & + & - & $\mathrm{ND}$ & - & - & - \\
\hline Mannitol & - & - & - & + & - & + & - \\
\hline Sorbitol & - & + & - & ND & - & - & - \\
\hline Sucrose & - & + & + & ND & + & - & - \\
\hline Xylose & - & - & - & + & - & + & - \\
\hline $\begin{array}{l}\text { DNA G + C content } \\
(\mathrm{mol} \%)\end{array}$ & $60 \cdot 0$ & $67 \cdot 0$ & $69 \cdot 6$ & $72 \cdot 5$ & $69 \cdot 4$ & $66-75$ & $66-72$ \\
\hline
\end{tabular}

(1980) and phylogenetic trees were constructed following the least-squares (Fitch \& Margoliash, 1967), maximumlikelihood (Felsenstein, 1981) and neighbour-joining (Saitou \& Nei, 1987) algorithms. Micrococcus luteus (M38242) was used as an outgroup to infer the root position (data not shown). Bootstrap analysis was performed with 1000 resampled datasets, using the SEQBOOT and CONSENSE programs of PHYLIP. Extraction of menaquinones and analysis by HPLC were carried out using a standard procedure (Minnikin et al., 1984). To determine fatty acid methyl esters, strains were cultivated on marine agar (Difco) at $25^{\circ} \mathrm{C}$ for $24-48 \mathrm{~h}$. Extraction and analysis of cellular fatty acids were performed according to the procedures for the SHERLOCK Microbial Identification System (MIDI Inc.).

Strain KMM $3905^{\mathrm{T}}$ formed aerobic, catalase-positive, coccoid, Gram-positive cells. The strain was able to grow in the presence of up to $15 \% \mathrm{NaCl}$, although its presence was not required for growth (Table 1 ). The $\mathrm{G}+\mathrm{C}$ content of the genomic DNA was $60 \mathrm{~mol} \%$. The cell envelope contained a major amount of 12-methyl-tetradecanoic acid (anteiso- $\mathrm{C}_{15: 0}$ ), and also smaller amounts of 14methyl hexadecanoic acid (anteiso- $\mathrm{C}_{17: 0}$ ) and 14-methyl pentadecanoic acid (iso- $\mathrm{C}_{16: 0}$; Table 2). The dominance of anteiso- $\mathrm{C}_{15: 0}$ is consistent for Kocuria, although the test was carried out in different media than reported previously (Table 2 ). The morphological, phenotypic and

Table 2. Fatty acid composition of $\mathrm{KMM} 3905^{\top}$ and six other species of the genus Kocuria

Strain/species: 1, KMM 3905 $;$; 2, K. kristinae; 3, K. palustris; 4, K. polaris; 5, K. rhizophila; 6, K. rosea; 7, K. varians. Data for reference species were taken from Stackebrandt et al. (1995), Kovács et al. (1999) and Reddy et al. (2003).

\begin{tabular}{|c|c|c|c|c|c|c|c|}
\hline Fatty acid & 1 & 2 & 3 & 4 & 5 & 6 & 7 \\
\hline iso- $\mathrm{C}_{14: 0}$ & $1 \cdot 9$ & $2 \cdot 6$ & $2 \cdot 2$ & & $1 \cdot 1$ & $1 \cdot 8$ & $1 \cdot 4$ \\
\hline $\mathrm{C}_{14: 0}$ & $2 \cdot 3$ & $1 \cdot 0$ & $3 \cdot 1$ & $1 \cdot 1$ & $2 \cdot 4$ & $1 \cdot 5$ & $2 \cdot 9$ \\
\hline iso- $\mathrm{C}_{15: 0}$ & $2 \cdot 5$ & $1 \cdot 6$ & $1 \cdot 0$ & $3 \cdot 2$ & $13 \cdot 8$ & $7 \cdot 6$ & $1 \cdot 3$ \\
\hline anteiso- $\mathrm{C}_{15: 0}$ & $74 \cdot 0$ & $70 \cdot 1$ & $59 \cdot 2$ & $70 \cdot 6$ & $48 \cdot 4$ & $70 \cdot 9$ & $60 \cdot 3$ \\
\hline $\mathrm{C}_{15: 0}$ & & & & & & & $1 \cdot 3$ \\
\hline $\mathrm{C}_{15: 1}$ & & $12 \cdot 1$ & $1 \cdot 0$ & & & & \\
\hline iso- $\mathrm{C}_{16: 0}$ & $7 \cdot 0$ & $1 \cdot 7$ & $3 \cdot 3$ & & $5 \cdot 9$ & $1 \cdot 6$ & $11 \cdot 1$ \\
\hline$C_{16: 0}$ & $2 \cdot 9$ & & $2 \cdot 1$ & $2 \cdot 4$ & $2 \cdot 6$ & $1 \cdot 6$ & $9 \cdot 6$ \\
\hline $\mathrm{C}_{16: 1}$ & & & & $2 \cdot 2$ & & $5 \cdot 9$ & \\
\hline iso- $\mathrm{C}_{17: 0}$ & & $9 \cdot 3$ & & $2 \cdot 9$ & $1 \cdot 2$ & & \\
\hline anteiso- $\mathrm{C}_{17: 0}$ & $8 \cdot 4$ & & $9 \cdot 7$ & $5 \cdot 6$ & $21 \cdot 1$ & $4 \cdot 3$ & $12 \cdot 1$ \\
\hline anteiso- $\mathrm{C}_{17: 1}$ & & & $3 \cdot 0$ & $4 \cdot 8$ & & $3 \cdot 0$ & \\
\hline iso- $\mathrm{C}_{18: 1}$ & & & $4 \cdot 6$ & & & & \\
\hline iso- $\mathrm{C}_{18: 0}$ & & & & $3 \cdot 0$ & & & \\
\hline $\mathrm{C}_{18: 0}$ & & & & $1 \cdot 2$ & & & \\
\hline $\mathrm{C}_{18: 1}$ & & & & & & & \\
\hline $\mathrm{C}_{18: 2}$ & & & $1 \cdot 4$ & & & & \\
\hline
\end{tabular}


chemotaxonomic descriptions of strain $\mathrm{KMM} 3905^{\mathrm{T}}$ are also consistent with its assignment to the genus Kocuria (Stackebrandt et al., 1995; Kovács et al., 1999).

In the phylogenetic analysis using 16S rRNA gene sequences, KMM $3905^{\mathrm{T}}$ formed an independent line within the Kocuria tree (Fig. 1). KMM $3905^{\mathrm{T}}$ had $16 \mathrm{~S}$ rRNA gene sequence similarities ranging from $96 \cdot 2$ to $98 \cdot 2 \%$ with other species of Kocuria. KMM $3905^{\mathrm{T}}$ was most closely related to K. rhizophila DSM $11926^{\mathrm{T}}$ and K. varians DSM $20033^{\mathrm{T}}$, and the topology of the branch for KMM $3905^{\mathrm{T}}$ and these two species was reproducible in the trees using least-squares and maximum-likelihood methods. K. rhizophila and $K$. varians have a close relationship with each other, sharing $98 \cdot 6 \% 16 \mathrm{~S}$ rRNA gene sequence similarity and are always recovered as a single cluster group in previous analyses. However, the two species are clearly distinguished on the basis of phenotypic and genotypic data such as physiological properties and DNA-DNA relatedness (Kovács et al., 1999; Reddy et al., 2003). The high bootstrap value between KMM $3905^{\mathrm{T}}$ and the $K$. rhizophila-K. varians group also strongly supported the tree topology of the three taxa (Fig. 1), indicating that the branching of KMM $3905^{\mathrm{T}}$ and the K. rhizophila-K. varians group is stable. $16 \mathrm{~S}$ rRNA gene sequence analysis clearly supports strain $\mathrm{KMM} 3905^{\mathrm{T}}$ as representing a separate phylogenetic lineage.

Strain KMM $3905^{\mathrm{T}}$ and other members of Kocuria were also separated on the basis of phenotypic characteristics; $\mathrm{KMM} 3905^{\mathrm{T}}$ grew at both 4 and $43^{\circ} \mathrm{C}$ and also in the

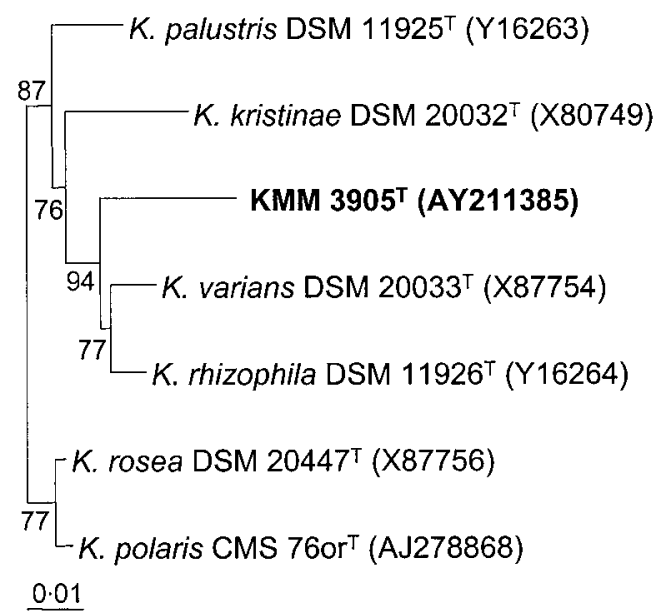

Fig. 1. Neighbour-joining tree based on the $16 \mathrm{~S}$ rRNA gene sequences of representative Kocuria species and strain KMM $3905^{\top}$. Kimura's two-parameter model was used to calculate phylogenetic distances among species. The topology of the entire tree was conserved in all trees using two different algorithms, namely Fitch-Margoliash and maximum-likelihood methods. Numbers at nodes are levels of bootstrap support from 1000 resampled datasets. Bar, 0.01 nucleotide substitutions per position. presence of $15 \% \mathrm{NaCl}$ (Table 1). Strain $\mathrm{KMM} 3905^{\mathrm{T}}$ showed different results in at least 11 tested characters from any other known species of Kocuria. The DNA G + C content of $\mathrm{KMM} 3905^{\mathrm{T}}$ was $60 \mathrm{~mol} \%$, the lowest reported among the members of the genus.

Total membrane fatty acids of members of Kocuria consist of major amounts of branched, saturated species (over $75 \%$ of the total), with minor amounts of straight or unsaturated fatty acids. In contrast, saturated species comprise over $90 \%$ of the total in all members (Table 2; Stackebrandt et al., 1995; Kovács et al., 1999; Reddy et al., 2003). KMM $3905^{\mathrm{T}}$, even allowing that the data were obtained from marine 2216 agar, has a unique fatty acid profile in that anteiso- $\mathrm{C}_{15: 0}$ comprises $74 \%$ of the total, though this is similar to the profiles for K. rhizophila and $K$. varians. $\mathrm{KMM} 3905^{\mathrm{T}}$, K. rhizophila and $K$. varians are also unique in that they do not contain any significant proportion of unsaturated fatty acids, whereas other species of Kocuria contain at least $7 \%$ unsaturated components.

From the polyphasic taxonomic evidence reported here, KMM $3905^{\mathrm{T}}$ clearly merits species status within Kocuria, for which we propose the name Kocuria marina sp. nov.

\section{Description of Kocuria marina sp. nov.}

Kocuria marina (ma.ri'na. L. fem. adj. marina of the sea).

Gram-positive, aerobic, non-motile, halotolerant coccoid cells. Positive for catalase, $\beta$-galactosidase and urease, but negative for arginine dihydrolase, lysine and ornithine decarboxylase, oxidase and alkaline phosphatase. Nitrate is reduced, but hydrogen sulphide is not produced. Production of indole and acetoin (Voges-Proskauer reaction) is negative. Growth occurs in the presence of up to $15 \%$ $\mathrm{NaCl}$, although its presence is not required for growth. Grows at $4-43^{\circ} \mathrm{C}$. Casein, gelatin and Tween 40 are hydrolysed, but agar, alginate, cellulose, DNA, starch, Tween 20 and Tween 80 are not. Glucose, lactose, mannose and sucrose are utilized as sole carbon sources, but not adonitol, L-arabinose, meso-inositol, mannitol, sorbitol, citric acid or malonic acid. Acid is produced from L-fucose, but not from acetic acid, $\mathrm{N}$-acetylglucosamine, adonitol, Larabinose, cellobiose, dulcitol, fumaric acid, galactose, glucose, glycerol, meso-inositol, lactose, malic acid, maltose, mannitol, melibiose, raffinose, rhamnose, sorbitol, sorbose, sucrose and L-xylose. Growth is inhibited by ampicillin, benzylpenicillin, carbenicillin, gentamicin, lincomycin, neomycin, oleandomycin, streptomycin and tetracycline, but not by kanamycin or polymixin B. Contains major amounts of branched, saturated fatty acids with 14 to $\sim 17$ carbons, among which 12-methyl-tetradecanoic acid (anteiso- $\mathrm{C}_{15: 0}$ ) is the predominant form. The $\mathrm{G}+\mathrm{C}$ content of the genomic DNA is $60 \mathrm{~mol} \%$.

The type and only strain is KMM $3905^{\mathrm{T}}\left(=\mathrm{KCTC} 9943^{\mathrm{T}}\right)$, isolated from marine sediment. 


\section{Acknowledgements}

This work was supported by grant no. KBM1000212 from the Korea Research Council of Fundamental Science \& Technology, Republic of Korea, grant 02-04-49517 from the Russian Foundation for Basic Research and grant 03-19 from the Ministry for Industry, Science and Technologies of the Russian Federation.

\section{References}

Boháček, J., Kocur, M. \& Martinec, T. (1969). Deoxyribonucleic acid base composition of Micrococcus roseus. Antonie van Leeuwenhoek 35, 185-188.

Felsenstein, J. (1981). Evolutionary trees from DNA sequences: a maximum likelihood approach. J Mol Evol 17, 368-376.

Felsenstein, J. (1993). PHYLIP (Phylogenetic Inference Package), version 3.5c. Distributed by the author. Department of Genetics, University of Washington, Seattle, USA.

Fitch, W. M. \& Margoliash, E. (1967). Construction of phylogenetic trees: a method based on mutation distances as estimated from cytochrome $c$ sequences is of general applicability. Science 155, 279-284.

Han, S. K., Nedashkovskaya, O. I., Mikhailov, V. V., Kim, S. B. \& Bae, K. S. (2003). Salinibacterium amurskyense gen. nov., sp. nov., a novel genus of the family Microbacteriaceae from the marine environment. Int J Syst Evol Microbiol 53, 2061-2066.

Kim, S. B., Falconer, C., Williams, E. \& Goodfellow, M. (1998). Streptomyces thermocarboxydovorans sp. nov. and Streptomyces thermocarboxydus sp. nov., two moderately thermophilic carboxydotrophic species isolated from soil. Int J Syst Bacteriol 48, 59-68.

Kimura, M. (1980). A simple method for estimating evolutionary rates of base substitutions through comparative studies of nucleotide sequences. J Mol Evol 16, 111-120.

Kloos, W. E. (1969). Transformation of Micrococcus lysodeikticus by various members of the family Micrococcaceae. J Gen Microbiol 59, 247-255.

Kloos, W. E., Tornabene, T. G. \& Schleifer, K. H. (1974). Isolation and characterization of micrococci from human skin, including two new species: Micrococcus lylae and Micrococcus kristinae. Int J Syst Bacteriol 24, 79-101.

Kocur, M. (1986). Genus Micrococcus Cohn 1872. In Bergey's Manual of Systematic Bacteriology, vol. 2, pp. 1004-1008. Edited by P. H. A. Sneath, N. S. Mair, M. E. Sharpe \& J. G. Holt. Baltimore: Williams \& Wilkins.

Kocur, M., Bergan, T. \& Mortensen, N. (1971). DNA base composition of Gram-positive cocci. J Gen Microbiol 69, 167-183.

Kocur, M., Kloos, W. E. \& Schleifer, K. H. (1991). The genus Micrococcus. In The Prokaryotes, 2nd edn, vol. 2, pp. 1300-1311. Edited by A. Balows, H. G. Trüper, M. Dworkin, W. Harder \& K. H. Schleifer. New York: Springer.

Kovács, G., Burghardt, J., Pradella, S., Schumann, P., Stackebrandt, E. \& Màrialigeti, K. (1999). Kocuria palustris sp. nov. and Kocuria rhizophila sp. nov., isolated from the rhizoplane of the narrow-leaved cattail (Typha angustifolia). Int J Syst Bacteriol 49, 167-173.

Minnikin, D. E., Goodfellow, M., Alderson, G., Athalye, M., Schaal, A. \& Parlett, J. H. (1984). An integrated procedure for the extraction of bacterial isoprenoid quinones and polar lipids. J Microbiol Methods 2, 233-241.

Ogasawara-Fujita, N. \& Sakaguchi, K. (1976). Classification of micrococci on the basis of deoxyribonucleic acid homology. J Gen Microbiol 94, 97-106.

Reddy, G. S. N., Prakash, J. S. S., Prabahar, V., Matsumoto, G. I., Stackebrandt, E. \& Shivaji, S. (2003). Kocuria polaris sp. nov., an orange-pigmented psychrophilic bacterium isolated from an Antarctic cyanobacterial mat sample. Int J Syst Evol Microbiol 53, 183-187.

Saitou, N. \& Nei, M. (1987). The neighbor-joining method: a new method for reconstructing phylogenetic trees. Mol Biol Evol 4, 406-425.

Stackebrandt, E., Koch, C., Gvozdiak, O. \& Schumann, P. (1995). Taxonomic dissection of the genus Micrococcus: Kocuria gen. nov., Nesterenkonia gen. nov., Kytococcus gen. nov., Dermacoccus gen. nov., and Micrococcus Cohn 1872 gen. emend. Int J Syst Bacteriol 45, 682-692. 